\title{
“ACID- ALKALI DEGRADATION STUDY ON OLMESARTAN MEDOXOMIL AND DEVELOPMENT OF VALIDATED STABILITY-INDICATING CHROMATOGRAPHIC METHODS"
}

\author{
BAHIA MOUSSA ${ }^{1}$, MARWA MOHAMED ${ }^{*}, 2$ NADIA YOUSSEF ${ }^{2}$

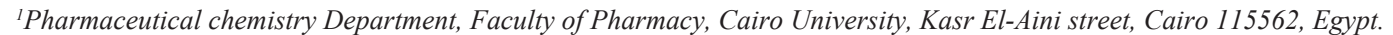 \\ ${ }^{2}$ National Organization for Drug Control and Research (NODCAR); 6 Abo Hazem Street, Pyramids Avenue, Post Office Box 29, Cairo, Egypt
} (Received: July 2, 2009 - Accepted: February 1, 2010)

\begin{abstract}
A reversed phase liquid chromatography (RP-HPLC) and thin layer chromatography (HPTLC) densitometry methods as a stability indicating assays of olmesartan medoxomil in presence of its acid or alkaline induced degradation products were developed. Olmesartan medoxomil and its degradation products were analyzed by HPLC equipped with UV-Variable wave length detector at $257 \mathrm{~nm}$ where quantitation was achieved by isocratic elution on Agilent, Exclipse XDB- $\mathrm{C}_{18}$ column with mobile phase composed of acetonitrile: methanol: water: glacial acetic acid (40:35:25:0.1 v/v/v/v) at flow rate $1 \mathrm{ml}$ min. ${ }^{-1}$. HPTLC was performed on aluminum packed Nano silica gel $60 \mathrm{~F}_{254}$ TLC plates as stationary phase with significant difference in R $f$ values between olmesartan medoxomil and its degradates using chloroform: methanol: formic acid $(8: 1.5: 0.5 \mathrm{v} / \mathrm{v} / \mathrm{v})$ as mobile phase. Densitometric evaluation of intact drug was carried out at $260 \mathrm{~nm}$. The calibration curve of olmesartan medoxomil in bulk form was linear from $0.5-10 \mu \mathrm{g} \mathrm{ml}^{-1}$ and $0.05-1 \mathrm{mg} \mathrm{ml}^{-1}$ with mean percentage accuracy $99.97 \pm 1.085$ $\%$ and $100.35 \pm 1.060 \%$ for HPLC and HPTLC methods, respectively. The two proposed methods were successfully applied for the determination of olmesartan medoxomil in drug substance and in drug product. Methods validation was tested for linearity; accuracy; precision; selectivity and robustness, according to USP guidelines.
\end{abstract}

Keywords: Olmesartan Medoxomil; HPLC; HPTLC; Acid- Alkali Degradation Product; Stability-Indicating.

\section{INTRODUCTION}

Olmesartan Medoxomil is an inactive ester prodrug that is completely hydrolyzed during absorption from the GIT to the active form olmesartan which is an angiotensin II receptor antagonist with antihypertensive activity due to mainly selective blockade of $\mathrm{AT}_{1}$ receptors and the consequent reduced pressor effect of angiotensin II, so it is used in the management of hypertension ${ }_{1-2}$. Olmesartan Medoxomil is non-official in any pharmacopeia up till now.

A limited number of publications were found in the literature concerning the determination of olmesartan medoxomil either in drug substance, drug product or biological fluids. Among those, HPLC procedures have been carried out for the determination of olmesartan in biological fluids using fluorescence detector $^{3}$ and coupled to tandem mass spectrometry ${ }^{4-5}$. A RP-HPLC assay was reported for the separation of related substances in olmesartan medoxomil ${ }^{6}$. Celebier et al presented an UV-VIS spectrophotometry and Capillary Zone Electrophoresis methods for the determination of olmesartan medoxomil in tablets ${ }^{7-8}$. A validated absorption factor spectrophotometric and HPLC methods for analysis of olmesartan medoxomil in combined pharmaceutical formulations were published ${ }^{9,10}$.

In the present study, a rapid, simple, accurate and reproducible validated chromatographic isocratic RP-HPLC and HPTLC analytical methods were developed for the quantitative estimation of olmesartan medoxomil in drug substance and in drug product without the interference of tablet excipients and its degradates. The proposed methods are suitable for the quality control analysis where the isocratic elution is simpler than gradient elution in routine analysis HPLC; HPTLC method was found to be easy, inexpensive, less time consuming and no need for complicated instruments. So, the two introduced methods are easily applicable in the national quality control laboratories in the developing countries.

\section{EXPERIMENTAL}

\section{Chemicals and Reagents}

- All the solvents used were of HPLC grade while the other chemicals were of analytical grade.

- Olmesartan Medoxomil was kindly supplied by BIG Pharma (Sabaa Co., Cairo, Egypt) and its purity found to be $99.53 \pm 0.54 \%$ according to drug substance in-house specifications ${ }^{11}$ cited a HPLC separation method using reversed phase column $\mathrm{C}_{18}$, mobile phase acetonitrile: $0.05 \mathrm{M}$ potassium dihydrogen phosphate $(50: 50 \mathrm{v} / \mathrm{v})$ at flow rate $1.5 \mathrm{ml} \mathrm{min}^{-1}$ and monitoring at the UV range $254 \mathrm{~nm}$.

- Olmetec film coated tablets (10 mg per tablet) were purchased from the local market in Egypt (manufactured by Sankyo Pharma, Germany).

Apparatus and Chromatographic Conditions:

For HPLC Method:

An Agilent technologies 1200 series consisted of isocratic pump (quaternary pump) Model G1310A/ G1311A liquid chromatographic system with $20 \mu 1$ loop manual injector was used. The analytes were separated on Agilent, Eclipse XDB-C ${ }_{18}$ column $(150 \mathrm{~mm}$ X 4.6 i.d., $5 \mu \mathrm{m}$ particle diameters, made in USA). The mobile phase was programmed to deliver $100 \%$ of acetonitrile: methanol: water: glacial acetic acid (40: 35:25: $0.1 \mathrm{v} / \mathrm{v} / \mathrm{v} / \mathrm{v})$ previously mixed together, filtered through $0.45 \mu \mathrm{m}$ nylon membrane filter and degassed through Agilent 1200 series vacuum degasser with flow rate $1 \mathrm{ml}$ min. ${ }^{-1}$ with isocratic elution and the UV- Variable wave length detector Model G1314B/ G13145 (SL) was set at $257 \mathrm{~nm}$. The column was conditioned for $\geq$ $30 \mathrm{~min}$. All the determinations were performed at ambient temperature $25 \pm 5$ ${ }^{\circ} \mathrm{C}$ using thermo stated column compartment Model G1316A/ G1316B and the injection volume was $20 \mu 1$.

\section{For HPTLC Method:}

High Performance Thin layer chromatographic aluminum plates, precoated with $0.20 \mathrm{~mm}$ Nano silica gel $60,10 \times 20 \mathrm{~cm}$ cut from $20 \times 20 \mathrm{~cm}$ plates, with fluorescent indicator at $254 \mathrm{~nm}$ (Macherey- NaGel (MN), Germany) were developed in chloroform: methanol: formic acid $(8: 1.5: 0.5 \mathrm{v} / \mathrm{v} / \mathrm{v})$ as the mobile phase. For detection and quantification, $10 \mu \mathrm{l}$ each of each sample solution and standard solutions of different concentrations within the linearity range were applied as separate compact spots $2 \mathrm{~cm}$ apart and $1 \mathrm{~cm}$ from the top and $2 \mathrm{~cm}$ from the bottom of the HPTLC plates using $25 \mu 1$ Hamilton syringe. The chromatographic glass tank $(20 \times 20 \times 10 \mathrm{~cm})$ was saturated with the mobile phase for one hour prior to development of the plates. The plates were developed up to $7 \mathrm{~cm}$ in the usual ascending way, air dried. The spots were detected under a UV- short wave length lamp at $254 \mathrm{~nm}$ and scanned at 260 $\mathrm{nm}$ with densitometric dual wave length SHIMADZU flying spot Cs-9301 PC (Japan) with spectrodensitometer parameters; photo mode: reflection; scan mode: Zigzag and swing width: $10 \mathrm{~mm}$.

- Unicam UV 300, thermospectronic, vision 32 software equipped with IBM PC computer used for all the absorbance measurements and treatment of data, HP laser jet 1000 series printer and $1-\mathrm{cm}$ path length quartz cuvettes. - Infra Red Spectroscopy; Jasco FT/ IR 460 plus, Japan.

Stock Solutions:

- Olmesartan Medoxomil stock solution $\left(0.5 \mathrm{mg} \mathrm{m}^{-1}\right)$ and working solution $\left(0.01 \mathrm{mg} \mathrm{ml}^{-1}\right)$ were prepared in the mobile phase for HPLC.

- Olmesartan Medoxomil stock solution $\left(1 \mathrm{mg} \mathrm{ml}^{-1}\right)$ in methanol for TLC.

- Degradation Product stock solution $\left(1 \mathrm{mg} \mathrm{ml}^{-1}\right)$ and working solutions (20 $\left.\& 0.2 \mu \mathrm{g} \mathrm{ml}^{-1}\right)$ in mobile phase for HPLC were prepared.

- Degradation Product stock solution $\left(1 \mathrm{mg} \mathrm{ml}^{-1}\right)$ and working solutions $\left(250,5 \mathrm{\mu g} \mathrm{ml}^{-1}\right)$ in methanol for TLC were prepared.

- Preparation of Degradation Product:

One hundred (100) milligrams of Olmesartan Medoxomil was dissolved in $100 \mathrm{~mL}$ of $1 \mathrm{M}$ hydrochloric acid and refluxed for one (1) hour or in $0.1 \mathrm{M} \mathrm{NaOH}$ for one (1) hour at room temperature, then stored in refrigerator. Complete degradation of olmesartan Medoxomil was ascertained by neutralizing acid degradation products with $1 \mathrm{M} \mathrm{NaOH}$ and alkaline degradation product with 
$0.1 \mathrm{M}$ HCL and applying the TLC technique using chloroform: methanol: formic acid $(8: 1.5: 0.5 \mathrm{v} / \mathrm{v} / \mathrm{v})$ as a developing solvent. Prior to each procedure, aliquots of degradation product solution were neutralized with $1 \mathrm{M} \mathrm{NaOH}$, filtered and diluted up to the required volume with mobile phase for HPLC and methanol for TLC.

\section{RECOMMENDED PROCEDURES}

\section{HPLC Method}

Aliquots of working solution $\left(0.01 \mu \mathrm{g} \mathrm{m} l^{-1}\right)$ equivalent to $2.5-50 \mu \mathrm{g}$ olmesartan medoxomil were transferred into a series of $5-\mathrm{ml}$ volumetric flasks and diluted up to the mark with mobile phase acetonitrile: methanol: water: glacial acetic acid $(40: 35: 25: 0.1 \mathrm{v} / \mathrm{v} / \mathrm{v} / \mathrm{v})$. Triplicate $20 \mu \mathrm{injections} \mathrm{of} \mathrm{each}$ solution were made; the procedure was performed as mentioned under HPLC chromatographic conditions. The peak area values were plotted against the corresponding concentrations and the regression equation was computed.

\section{HPTLC Method}

Aliquots of stock solution ( $\left.1 \mathrm{mg} \mathrm{ml}^{-1}\right)$ equivalent to $0.25-5 \mathrm{mg}$ olmesartan medoxomil were transferred into a series of 5- $\mathrm{ml}$ volumetric flasks and diluted up to the mark with methanol. A ten (10) $\mu 1$ of each solution was spotted on HPTLC plates. The procedure was carried out as mentioned under HPTLC chromatographic conditions. The peak area values were plotted against the corresponding concentrations and the regression equation was computed.

Drug Product Preparation

Ten tablets were weighed, decoated and finely powdered. An amount of powder equivalent to $25 \mathrm{mg}$ of olmesartan medoxomil for HPLC and $50 \mathrm{mg}$ for HPTLC was extracted in $40 \mathrm{ml}$ mobile phase for HPLC and $40 \mathrm{ml}$ methanol for TLC, sonicated for $30 \mathrm{~min}$, filtered, transferred quantitatively into 2 separate 50 - ml volumetric flasks and completed with appropriate solvents to the mark. The assay was completed as described under recommended procedures. The concentration was calculated using the corresponding regression equation.

\section{RESULTS and DISCUSSION}

\section{Elucidation of the degradation products}

Stability study was carried out on olmesartan medoxomil (Fig.1), in acidic $(1 \mathrm{M} \mathrm{HCl})$ and alkaline $(0.1 \mathrm{M} \mathrm{NaOH})$ media. Olmesartan Medoxomil degradation products were obtained by reflux in $1 \mathrm{M} \mathrm{HCl}$ for one hour while degradation in $0.1 \mathrm{M} \mathrm{NaOH}$ occurred when solution was left on the bench for one hour. The prepared acidic and alkaline degradation products were elucidated by HPLC, TLC, UV and IR. These investigations proved that acidic and alkaline degradates are nearly similar molecules where both degradates have the same RT in HPLC (Fig. 2), R $f$ on the TLC plates (Fig.3), UV spectra (Fig.4) and IR spectra where the IR spectra of acid and alkali degradates shows the appearance of the characteristic N-H bending at $1595.81 \mathrm{~cm}^{-1}$ and $\mathrm{O}-\mathrm{H}$ stretching at $3435.56 \mathrm{~cm}^{-1}$ and the disappearance of the two carbonyl groups present at $1706.69 \mathrm{~cm}^{-1}$ and $1831.08 \mathrm{~cm}^{-1}$ in the IR spectrum of the intact drug (Fig.5). On the TLC plates, it was observed that acid degradate was separated into two spots near each other (Fig.3) having the same UV and IR spectra and were suggested to be enantiomeric degradates.<smiles>CCCc1nc(C(C)(C)O)c(C(=O)OCc2oc(=O)oc2C)n1Cc1ccc(-c2ccccc2-c2nn[nH]n2)cc1</smiles>

Fig.1. Structure of Olmesartan Medoxomil
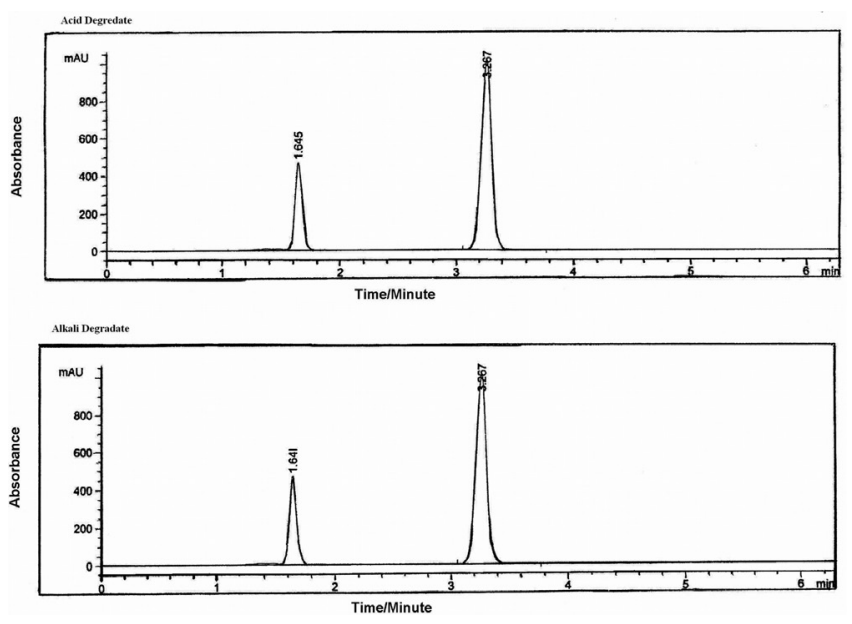

Fig.2. HPLC chromatogram of olmesartan medoxomil $\left(10 \mu \mathrm{g} \mathrm{m}^{-1}\right)(\mathrm{RT}=$ $3.267 \mathrm{~min}$.) and its acid \& alkali degradates $\left(4 \mu \mathrm{g} \mathrm{ml}^{-1}\right)(\mathrm{RT}=1.645,1.641)$ at $257 \mathrm{~nm}$.

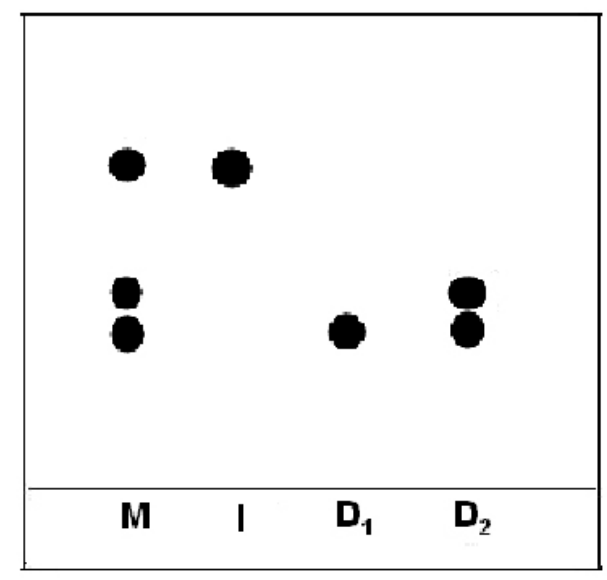

Fig.3. TLC Figure of:

- M: Mixture of Olmesartan Medoxomil (I, $1 \mathrm{mg} \mathrm{ml}^{-1}$ ), acid and alkali degradates $\left(\mathrm{D}_{1} \& \mathrm{D}_{2}, 0.2 \mathrm{mg} \mathrm{ml}^{-1}\right)$.

- I: Olmesartan Medoxomil intact $\left(1 \mathrm{mg} \mathrm{ml}^{-1}\right)$.

- $D_{1}$ Alkali Degradation product $\left(0.2 \mathrm{mg} \mathrm{ml}^{-1}\right)$.

$-\mathrm{D}_{2}$ : Acid Degradation product $\left(0.2 \mathrm{mg} \mathrm{ml}^{-1}\right)$.

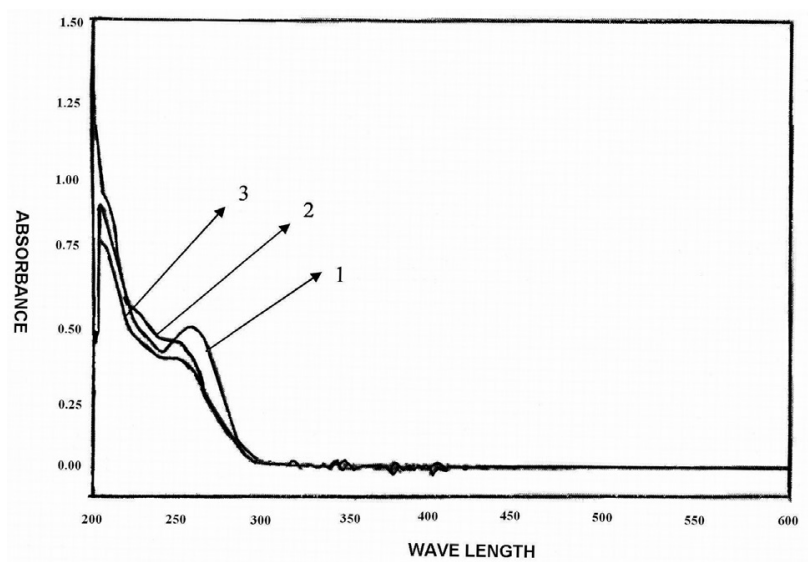

Fig.4. The absorption spectra of:

(1) Olmesartan Medoxomil intact $\left(10 \mu \mathrm{g} \mathrm{ml}^{-1}\right)$.

(2) Alkali \& (3) Acid degradates $\left(10 \mu \mathrm{g} \mathrm{ml}^{-1}\right)$ in methanol. 

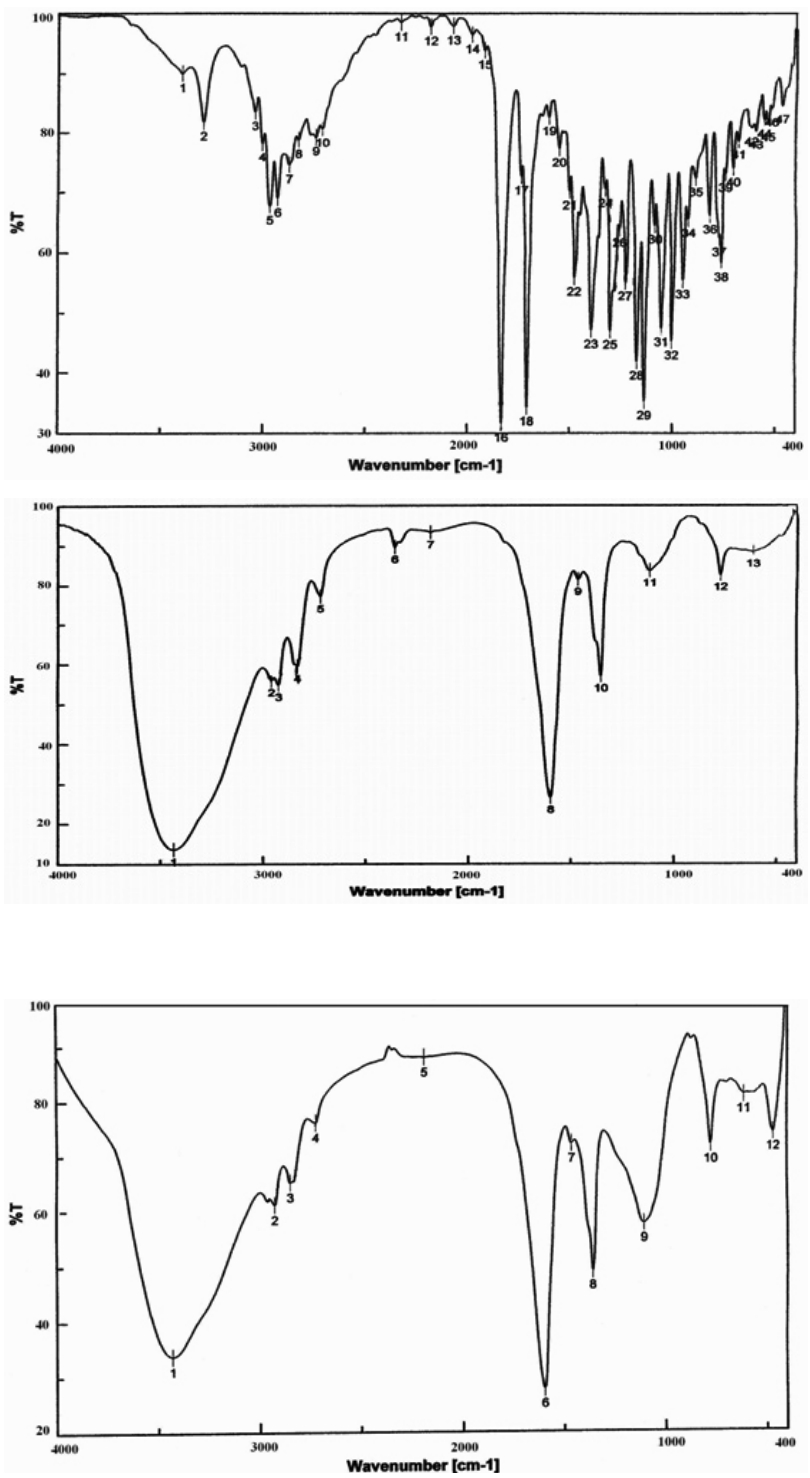

Fig.5. The IR Spectrum of (A) Olmesartan Medoxomil Intact

(B) Acid Degradation Product

(C) Alkaline Degradation Product

\section{Method Development}

\section{HPLC Method:}

In HPLC, the elution order was the degradates at RT=1.645 and 1.641 min. and olmesartan medoxomil at RT=3.267 min. at $257 \mathrm{~nm}$ with flow rate 1 $\mathrm{ml} \mathrm{min.}{ }^{-1}$ using acetonitrile: methanol: water: glacial acetic acid (40:35:25:0.1 $\mathrm{v} / \mathrm{v} / \mathrm{v} / \mathrm{v}$ ) as mobile phase (Fig. 2). Linearity was obtained for the concentrations range $0.5-10 \mu \mathrm{g} \mathrm{ml}^{-1}$ with mean percentage accuracy $99.97 \pm 1.085 \%$; the parameters of regression equation are shown in (Table 1). The system suitability tests of HPLC method were evaluated (Table 4).

\section{HPTLC Method:}

In HPTLC, complete separation was obtained using chloroform: methanol: formic acid $(8: 1.5: 0.5 \mathrm{v} / \mathrm{v} / \mathrm{v})$ as a developing mobile phase. The intact and degradation product were satisfactorily resolved with $\mathrm{R} f$ values $\pm \mathrm{S}$.D were $0.70 \pm 0.01,0.55 \pm 0.01$ and $0.53 \pm 0.30$, respectively (Fig.3). The densitometric evaluation of separated zones was performed at $260 \mathrm{~nm}$ (Fig.6). Linearity was obtained in the concentration range $0.05-1 \mathrm{mg} \mathrm{ml}^{-1}$ with mean percentage accuracy $100.35 \pm 1.060 \%$, the parameters of regression equation is shown in (Table 1).

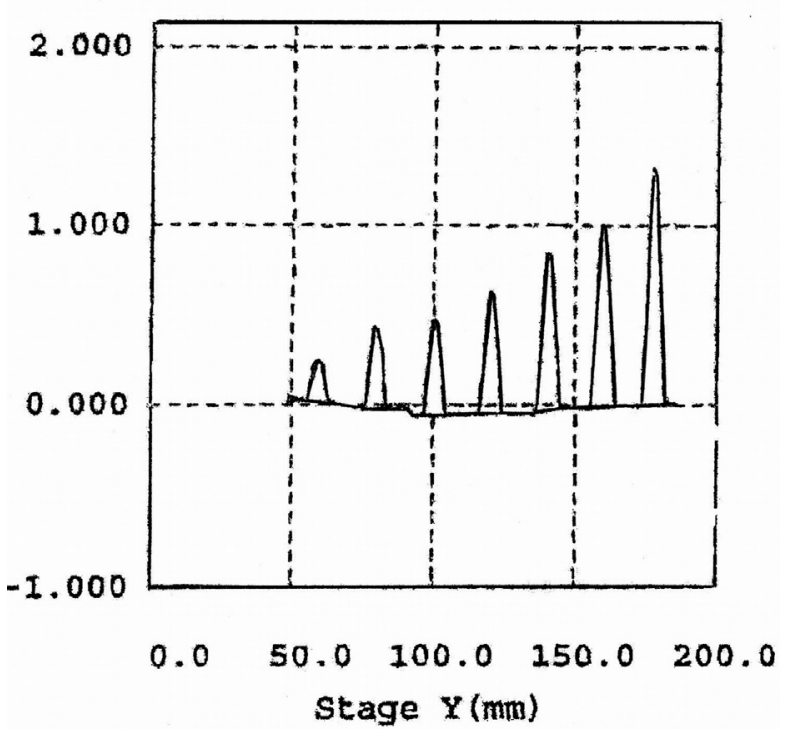

Fig.6. TLC scanning profile of Olmesartan Medoxomil (0.05-1 $\left.\mathrm{mg} \mathrm{m}^{-1}\right)$ at $260 \mathrm{~nm}$

\section{Method Validation}

Linearity:

The calibration curves of the two proposed methods were constructed with different concentrations ranging from $0.5-10 \mu \mathrm{g} \mathrm{ml}^{-1}$ for HPLC and $0.05-1 \mathrm{mg}$ $\mathrm{ml}^{-1}$ for HPTLC. The linearity was evaluated by linear regression analysis to calculate the slope, intercept and regression coefficient $\left(\mathrm{r}^{2}\right)$ (Table1).

Table1. Analytical and Validation parameters for the determination of Olmesartan Medoxomil by HPLC and HPTLC Methods.

\begin{tabular}{|c|c|c|}
\hline Parameters & HPLC Method & TLC Method \\
\hline Wavelength $(\mathrm{nm})$ & 257 & 260 \\
\hline specificity $(\text { mean } \pm \text { R.S.D } \%)^{a}$ & $100.08 \pm 1.383$ & $100.13 \pm 1.389$ \\
\hline Linearity range & $0.5-10 \mu \mathrm{g} \mathrm{ml}^{-1}$ & $0.05-1 \mathrm{mg} \mathrm{ml}^{-1}$ \\
\hline $\begin{array}{c}\text { Regression Equation }^{6} \\
\text { Slope }(b) \\
\text { Intercept }(a)\end{array}$ & $\begin{array}{l}43.619 \\
6.7437\end{array}$ & $\begin{array}{l}804.36 \\
1619.2\end{array}$ \\
\hline Regression coefficient $\left(\mathrm{r}^{2}\right)$ & 0.9997 & 0.9997 \\
\hline $\begin{array}{c}\text { Precision }( \pm \text { R.S.D \%) } \\
\text { Intraday }^{\mathrm{c}} \\
\text { Interday }^{\mathrm{c}}\end{array}$ & $\begin{array}{l} \pm 1.170 \\
\pm 1.482\end{array}$ & $\begin{array}{l} \pm 1.181 \\
\pm 1.350\end{array}$ \\
\hline $\begin{array}{c}\text { Accuracy }(\text { mean } \pm \text { R.S.D } \%)^{\mathrm{d}} \\
\text { Drug substance } \\
\text { Drug product } \\
\text { Standard added }\end{array}$ & $\begin{array}{c}99.97 \pm 1.085 \\
102.90 \pm 1.818 \\
100.74 \pm 1.469\end{array}$ & $\begin{array}{c}100.35 \pm 1.060 \\
103.14 \pm 1.742 \\
99.84 \pm 1.737\end{array}$ \\
\hline
\end{tabular}

a Average of $\mathrm{n}=6$ for HPLC method.

${ }^{\mathrm{b}} y=a \pm b c$ where $\mathrm{c}$ is the concentration of drug $\mu \mathrm{g} / 20 \mu \mathrm{l}$ for HPLC, $\mu \mathrm{g} /$ spot for TLC methods, $y$

the peak area for HPLC and TLC at the specified wave length.

${ }^{c}$ Average of $\mathrm{n}=9$

dAverage of $\mathrm{n}=5$

Accuracy:

The accuracy of the two proposed methods in drug substance was determined by the analysis of different concentrations of intact solution, each in triplicate within one day and the results were compared with those of the reported method ${ }^{11}$ where no significant difference was observed between the calculated student's $t$ test and variance ratio $F$ test values and the theoretical ones (Table 2). The recovery method was studied by analyzing samples of tablets formulation without the interference of tablet excipients; also the 
standard addition technique was applied by adding a known amount of standard drug to the drug product and the results were expressed as mean \pm R.S.D \%, (Table 1).

Table2. Statistical comparison of results for the determination of Olmesartan Medoxomil in drug substance by the proposed Methods and the reported Method.

\begin{tabular}{|c|c|c|c|}
\hline Values & $\begin{array}{c}\text { HPLC } \\
\text { Method }\end{array}$ & $\begin{array}{c}\text { TLC } \\
\text { Method }\end{array}$ & $\begin{array}{c}\text { Reported }^{\mathrm{c}} \\
\text { Method }^{11}\end{array}$ \\
\hline Meana$^{\mathrm{a}}$ R.S.D \% & $\begin{array}{c}99.97 \pm \\
1.085\end{array}$ & $100.35 \pm 1.060$ & $99.53 \pm 0.54$ \\
\hline S.D & 1.084 & 1.063 & 0.54 \\
\hline S.E & 0.485 & 0.476 & 0.24 \\
\hline Variance & 1.176 & 1.131 & 0.29 \\
\hline$t(2.31)^{\mathrm{b}}$ & 0.808 & 1.524 & \\
\hline$F(6.39)^{\mathrm{b}}$ & 3.995 & 3.841 & \\
\hline
\end{tabular}

${ }^{\text {a }}$ Average of $\mathrm{n}=5$ for HPLC, TLC and reported method.

${ }^{b}$ Theoretical values of $t$ and $F$ at $95 \%$ confidence level.

c HPLC procedure using $\mathrm{c}_{18}$ column, Acetonitrile: 0.05 Potassium Dihydrogen Phosphate $(50: 50 \mathrm{~V} / \mathrm{V})$ as mobile phase and UV detector at 254 nm.

\section{Precision:}

The intra-day and inter-day variations were expressed by \pm R.S.D \%, (Table 1), were determined by using triplicate analysis of three different concentrations $\left(2,6,10 \mu \mathrm{g} \mathrm{ml}^{-1}\right.$ for HPLC); $\left(0.2,0.4,0.6 \mathrm{mg} \mathrm{ml}^{-1}\right.$ for HPTLC) over a period of three days (Table 1 ).

Specificity:

The specificity of the two proposed methods was determined by preparing laboratory mixtures of intact and its degradation product containing 0.1- 100 $\% \mathrm{w} / \mathrm{w}$ of the degradation product (Table 3 ). The assay results are unaffected by the presence of extraneous materials (degradates, excipients such as micro crystalline cellulose, lactose monohydrate, hydroxyl propyl cellulose, low substituted hydroxyl propyl cellulose, magnesium stearate, titanium dioxide (E171), talc, hypromellose ) ${ }^{12}$. The good results of laboratory- prepared mixtures prove the specificity of proposed methods (Table 3 ).

Table3. Determination of Olmesartan Medoxomil by the proposed methods in presence of its degradation products

\begin{tabular}{|c|c|c|c|}
\hline $\begin{array}{c}\text { Sample } \\
\text { Number }\end{array}$ & $\begin{array}{c}\text { \% of degradation } \\
\text { products }\end{array}$ & $\begin{array}{c}\text { HPLC Method } \\
\text { found } \%\end{array}$ & $\begin{array}{c}\text { HPTLC } \\
\text { Method }^{\mathrm{b}} \\
\text { found } \%\end{array}$ \\
\hline 1 & 0.1 & 101.59 & 101.68 \\
\hline 2 & 0.5 & 100.45 & 100.75 \\
\hline 3 & 5 & 98.65 & 98.36 \\
\hline 4 & 10 & 101.23 & 98.66 \\
\hline 5 & 50 & 100.37 & 101.37 \\
\hline 6 & 100 & 98.15 & 99.98 \\
\hline $\begin{array}{c}\text { Mean } \\
\pm \text { R.S.D } \%\end{array}$ & & $100.08 \pm 1.383$ & $100.13 \pm 1.389$ \\
\hline
\end{tabular}

a Calculated with respect to intact weight (degradation products -drug mixture wt $/ \mathrm{wt} \%)$.

${ }^{\mathrm{b}}$ Found $(\%)$ of intact sample.

${ }^{c}$ Average of $\mathrm{n}=6$ for HPLC and TLC method.

\section{System Suitability of HPLC Method:}

The \% R.S.D of injection repeatability and retention time for drug substance are within $2 \%$ indicating the suitability of the system (Table 4). The efficiency of the column as expressed by the number of theoretical plates was 6955 and the tailing factor was 0.6 (Table 4).
Table 4. Results of System Suitability Tests of HPLC Method

\begin{tabular}{|c|c|c|}
\hline Parameters & Values & Comments \\
\hline Retention Time & $3.261 \pm 0.040$ & \pm Standard deviation \\
\hline Injection Repeatability & 1.212 & RSD for five injections \\
\hline K & 2.16 & Capacity factor \\
\hline Selectivity Factor $(\alpha)$ & 3.66 & $\begin{array}{c}\text { Separation factor calculated } \\
\text { as } \mathrm{K}_{2} / \mathrm{K}_{1}\end{array}$ \\
\hline Tailing Factor & 0.63 & $\begin{array}{c}\text { calculated at } 5 \% \text { of peak } \\
\text { height }\end{array}$ \\
\hline Theoretical Plates (N) & 6955 & $\begin{array}{l}\text { Column efficiency } \\
\text { theoretical Plate/ column }\end{array}$ \\
\hline HETP & 0.02 & $\begin{array}{l}\text { Height equivalent } \\
\text { theoretical plate }\end{array}$ \\
\hline Resolution & 3.244 & Calculated by $2\left(\mathrm{t}_{2}-\mathrm{t}_{1}\right) / \mathrm{w}_{2}+\mathrm{w}_{1}$ \\
\hline
\end{tabular}

\section{Robustness:}

Two sets of experiments were performed on Agilent 1200 series HPLC and HPTLC densitometry by two different analysts in different days with respect to the peak area as a response factor calculated and expressed as \pm R.S.D $\%$ and no significant difference was obtained between the results in this study. Also, small changes in the composition of the mobile phase of both methods did not affect on the response factor.

\section{CONCLUSION}

This paper described RP-HPLC and HPTLC methods which can be used as stability indicating assay for the determination of olmesartan medoxomil in presence of its degradates and in drug product without interference from tablet excipients. The advantages of the suggested methods were the ease of performance, the reproducibility and the lack of complicated pretreatments before analysis. In addition these methods have a potential application in quality control laboratories.

\section{REFERENCES}

1. S.C Sweetman Martindale "The Complete Drug Reference". The Pharmaceutical Press, London, 2009; pp 1361.

2. L.L. Brunton, J.S. Lazo, K.L. Parker Goodman and Gilman's "The Pharmacological Basis of Therapeutics". McGraw-Hill book Co., New York, NY, 2006; p 959.

3. J.F. Liu, J. Wang, Y. Yu, Y.N. Hou. J Yaowu Fenxi Zahi 26(5), 595 (2006).

4. V.V. Vaidya, S.M.N. Roy, S.M. Yetal, S.S. Joshi, S.A. Parekh. J Chromatog. 67(1-2), 147 (2008).

5. D.Y. Liu, P. Hu, N. Matsushima, X.M. Li, L. Li, J. Jiang. J chromatogr. B Anal. Technol. Biomed. Life Sci. 856 (1-2), 190 (2007).

6. S.W. Weng. J Yaowu Fenxi Zahi 26(5), 686 (2006).

7. M. Celebier, S. Altionz. J. Pharmazie 62 (6), 419 (2007).

8. M. Celebier, S. Altionz. J. Chromatogr., 66(11/12), 929 (2007).

9. O. Sagirili, A. Onal, S.E. Toker, D. Sensoy. J Chromatogr. 66 (3-4), 213 (2007).

10. C.V. Patel, A.P. Khandhar, A.D. Captain, K.T. Patel. J Anal. Chem. 2(3), 159 (2007).

11. Raw Material In-House specifications Bi-original International Group (BIG) Cairo, Egypt.

12. Http://emc.medicines.org.uk/document.aspx?document1d=15152. 